\title{
THE NIGERIAN INSURANCE INDUSTRY COMPETITIVE ADVANTAGE: THE ROLE OF INNOVATION CAPABILITY
}

\author{
UDC 368(669)
}

\section{Sunday Abayomi Adebisi, Joyce M. Odiachi, Abdul-Hammed A. Sulaimon}

\author{
University of Lagos, Lagos, Nigeria
}

\begin{abstract}
Emerging technologies have given rise to greater opportunities within the insurance sector with innovations upturning the traditional business model. This study examined competitive advantage and the relationship with innovation capability in Nigerian insurance sector. Employing a cross sectional research design, the study utilised primary data obtained from selected insurance companies through the use of a structured questionnaire. Multistage sampling technique was used and data collected was analysed using regression analysis. The findings revealed innovation capability had a significant influence on competitive advantage. The study concluded that there was a need to pay attention to this capability with a capacity to boost the activities of the industry and recommendations were made.
\end{abstract}

Key words: Competitive advantage, insurance, innovation capability

JEL Classification: $\mathrm{O} 31, \mathrm{O} 32$

\section{INTRODUCTION}

Organisations that aspire to effectively sustain competitive advantage may require an edge to contest on the boundaries of competence and technology. Increased force in terms of product development, ease of imitation and shorter product life cycles amid global market competition, have created immense pressure on organisations' activities geared towards innovation and their bid to sustain competitive advantage (Chadha, 2009). Porter (1985) observed technological change as one of the major catalysts of competition and is

Received December 11, 2020 / Revised January 21, 2021 / Revised February 12, 2021 / Accepted February 17, 2021

Corresponding author: Joyce M. Odiachi

University of Lagos, Lagos, Nigeria

E-mail: joycemodiachi@gmail.com 
not important for its own sake, but for the effect it has on competitive advantage and industry structure.

According to Iddris (2016), latest changes in technology, market conditions as well as variations in consumer preferences, have shown the importance of innovation capability to an organisation and its survival.

Innovation activity is the ability of an organisation to replicate innovation success and has been recognised as an essential source of competitive advantage (Aas \& Breunig, 2017; Calantone, Cavusgil \& Zhao, 2002). Innovation helps insurance firms reduce costs, create efficiencies in service delivery, improved flexibility and demand for its products and services (Ernst \& Young, 2015). An organisation's ability to change the base of its resource by crafting, incorporating, recombining and discharging same is referred to as capability (Eisenhardt and Martin, 2000).

Breakthrough technologies such as cloud computing, data analytics, telematics, and so on have spurred fundamental transformation of the insurance industry worldwide. These same innovations may perhaps assist the Nigerian insurance industry enhance its product offerings, create better efficiencies in customer experience, minimise the claims processing time amongst others. These technologies are enabling new product creation and business models (IIF, 2016). Whilst these emerging technologies offer opportunities for growth, practitioners with the existing old models, are forced to respond to these changes. The last few decades have seen the rise in globalisation which has shrunk the barriers in trade across continents thus enabling cross continent business and has inadvertently given rise to the need for insurance on a global scale. It is thus expected that companies who want to play within this global space, have capabilities that will enable them offer customers a robust platform to deal with regarding insurance.

The resource-based view theory (RBV) has been repeatedly employed as the base theory in terms of organisational resources usage to attain competitive advantage. When referring to the RBV, it does not relate only to just resources, but also attributes, required by these resources in order to gain competitive advantage (Barney \& Clark, 2007). For organisations to gain competitive advantage, they require competitive positioning further than their marginal competitor (Peteraf \& Barney, 2003). Organisations' leaders devise strategies and allocate resources to meet goals. To achieve this, technology is required for value creation, seamless integration and improved competitive advantage. The need to pay attention to value creation has risen due to an increased demand for insurance. The focus for organisations may perhaps be delivering products and services to customers that are appropriate and align with their needs as against selling to them existing products, with an obligation to meet these demands through improved capacity while still keeping an eye on making a difference.

Insurance is more or less a promise that cannot be seen, as such, a certain level of guarantee is required and this guarantee is very important to the customer. Mathur and Tripathi (2014) note that the reinforcement of this comfort is further guaranteed when the customers believe and experience differentiated processes, speed and efficiency. Challenges within the insurance sector cut across a plethora of issues from political, regulatory to technological, which all exert pressure thus leading to increased competition with little or no effort to diversify (Rajapathirana \& Hui, 2017). Developments and changes in technology, growth within the economy, regulatory frameworks have all started calling for new techniques in the way things are done. While some of these frameworks like recapitalisation, will help create excess liquidity and opportunities for the companies to improve their level 
of innovative offering, others such as product guidelines may unwittingly suffocate innovation (Abongo, Mutinda and Otieno, 2019).

In recent times, there have been quite a number of innovations globally in the insurance sector relating to telematics, customer relations management, big data, product innovation, amongst others (Klapkiv \& Klapkiv, 2017). The use of big data is to mine information in profiling customers, identifying specific needs, innovating new products to suit these needs and enhancing product offerings. Better efficiencies are also created in customer experience with the use of customer relationship management tools that assist to store information, recognize sales opportunities, record possible service issues and give opportunity for improvement. Another benefit to the insurance industry is the use of telematics in the tracking of vehicles which has become quite common and assist in the recovery of vehicles when stolen. These and many more, may assist the industry create more interconnections, improve risks management and enhance service delivery.

According to Czerniak and Klapkiv (2018), the process of underwriting is a major stage in an insurance contract. Gnatzy and Moser (2012) in a study note that there is a need to have an innovation business model that is designed for insurance, while on the other hand, Maina (2016) observe that there existed very poor implementation within insurance companies of innovation strategies and sound management programs designed towards innovation which could help create competitive advantage. The Nigerian financial sector has quite a number of players within the insurance sub-sector which is the $5^{\text {th }}$ largest insurance market in sub-Saharan Africa with reports however, that contribution to the GDP and penetration rate is still lower than most other African countries (PWC, 2015). The industry Gross Premium income grew from N300bn in 2017 to N413bn in 2018 (NIA, 2018). Despite this improvement, Nigeria still is one of the few countries with such a huge market base to invest less in innovation capability.

According to Porter (1996), organisations who focus more on strategic positioning by executing different tasks than their contenders or comparable jobs in a unique way, rather than operational efficiency as a source of competitive positioning stand a better chance of attaining competitive advantage. Application of strong innovation capability may improve the competitive advantage of insurance companies in Nigeria.

Several studies have shown that innovation capability facilitates competitive advantage, most of these studies have focused on developed economies with a few on the developing economies, some on other sectors of the economy, while others on marketing or claims management (Alsamydai, Alnawas \& Yousif, 2010; Bell and Figueiro, 2012; Rajapathirana $\&$ Hui, 2017; Anand \& Monin, 2013). However, to the knowledge of these researchers, there seems to be very little highlighted on innovation within the underwriting process in the Nigerian insurance industry. To address this gap, this study explores companies within the sector and seeks to examine the relationship between innovation capability and competitive advantage. In line with the above objective, research question was asked and hypothesised thus:

Innovation capability will not influence competitive advantage in the Nigerian insurance industry.

\subsection{Theoretical Underpinning}

The resource-based view theory underpins this study. It acknowledges organisational resource as a mixture of its assets, information, knowledge, processes and capabilities 
within its control and assists in the conceptualisation and implementation of various strategies that have positive impact on the organisation (Kimani \& Juma, 2015). The RBV theory as popularised by Wernerfelt (1984) and Barney (1991) is a well-known viewpoint in strategic management which states that every organisation requires specific competences and resources to sustain its competitive position.

Capabilities are complex patterns of skills which the RBV theory explains as a combination of a firm's skills and knowledge accumulated over time (Zhou, Pan \& Urban, 2018). Innovation capability may be categorised as an intangible resource. According to Rua, Franca and Ortiz, (2017), intangible assets are considered to be strategic variables and sources of sustainable value.

In line with the RBV theory, it is the conception, ownership, management and distribution of intangibles that expound variations in performance. Resources, where they assist an organisation in improving its performance, may be designated strategic instruments (Massey, 2016). According to Wu, Gu and Zhang (2008) innovation capabilities are the abilities of an organisation to create and transmit to financial practice, new technological potentials that have the ability to respond to the changing environment. RBV theory supposes that a relationship exists between the resources and capabilities being deployed and competitive advantage (Shan, Luo, Zhou \& Wei, 2019). It is thus not farfetched, in the context of this study, to say that innovation capability being an intangible asset and acting as an organisational resource, may perhaps be critical to competitive advantage of insurance firms.

\subsection{Innovation Capability (IC)}

Innovation is a tactical tool for organisations in their quest for competitive advantage and sustainable performance and its significance has repeatedly improved and supported the growth of businesses globally (Chaudhry \& Verma, 2016). Zawislak, Fracasso and TelloGamarra (2018) describe innovation as a means of competitive advantage and an organisation's ability to absorb, alter and adapt into particular managerial and operational routines, a certain technology that has the capacity to lead the organisation to immense profitability and thus preserve itself. The OECD (2005) describe innovation as the implementation of a process, new method in business practice or marketing, or implementation of a new product or an improved product, goods or service that impacts the organisation or its external relations. Studies on innovation have established that innovation not only is the opening up of new markets, but also the offering of new ways to serve existing and established markets (Lambert \& Davidson, 2013). Innovation as a basis of a business's advantage is a consolidated subject in literature, and is viewed as a process dependent on technological capability (Katz, 1984; Desai, 1984; Lall, 1992).

Capability as a concept is not a parameter for performance, but a guide as to the level to which an organisation is prepared in terms of development of innovation forces (Borjesson \& Elmquist, 2011). Innovation capability is, therefore, defined as the capacity of an organisation to identify new ideas and transform the same into new products, improved services and processes that are beneficial to the organisation. Rajapathirana and Hui (2018) observed that innovation is more a matter of survival than of competitive advantage. Innovation capability can be described as the capacity of an organisation to identify new ideas and transform the same into new products, improved services and processes that are beneficial to the organisation. It is entrenched with all the strategies and structure that are in support of innovation in an organisation (Gloet \& Samson, 
2016). An organisation's innovation capability according to Lerro, Linzalone and Schiuma (2014), is the skill to transform continuously ideas and knowledge and convert to new products, processes and systems that are beneficial to the organisation and other stakeholders. The study viewed IC from the perspectives of process, product, market and organizational innovation.

Existing literature has focused on different aspects of innovation and revealed a positive relationship between innovation activities implementation and organisational performance (Slater, Mohr \& Sengupta, 2014; Vicente, Abrantes \& Teixeira, 2015; Hill, Brandeau, Truelove \& Lineback, 2015). IC has been measured as a single dimension, a dichotomous construct and multi-dimensional (Cavusgil, Calantone \& Zhao, 2003; Cassiman \& Golovko, 2011). This study, while adopting the definition of Lerro et al. (2009), will view innovative capability as a uni-dimensional construct.

\subsection{Competitive Advantage (CA)}

Competitive advantage is exhibited as positional advantage greater than that of competitors in either marketing or technological know-how which translates into hard-toimitate innovative products (Hwang, Choi \& Shin, 2020). According to Barney and Hesterly (2009), competitive advantage is the ability of a company to produce a higher amount of financial worth than their competitors. The art of creating value for an organisation's client in a more improved manner than the competition is competitive advantage which can be achieved through differentiation, focus and cost strategies (Porter, 2008). Peteraf (1993) noted that an organisation that wishes to have competitive advantage, needs to ensure that resources are properly matched to environmental opportunities.

The RBV premises that an organisation's specific capabilities are warehoused within a single firm and the search for competitive advantage lies therein (Wernerfelt, 1984). With the increase in global rivalry for supremacy by organisations, achieving and sustaining competitive advantage may have become important. Stevenson (2009) noted that the achievement of an organisation in the deployment of its resources in meeting requests of its consumers when compared to their competitors is the measure of competitive advantage. For an organisation to effectively sustain competitive advantage, they need to look inwards to their unique resources and capabilities that they have control over and ensure that the foundation of its advantage is not easily duplicated by competitors (Chen, Zhou, Zhou \& Xue, 2017; Mahdi, Nassar \& Almsafir, 2018). Several extant literatures have defined and measured competitive advantage in various ways (Christensen \& Fahey, 1984; Stevenson, 2009), this study while reviewing as a uni-dimensional construct, will adopt the definition of Li, Ragu-Nathan, Ragu-Nathan and Rao (2006).

\subsection{Innovation Capability and the Insurance Industry Competitive Advantage}

Insurance the world over has grown over time, Africa and Nigeria not excluded. Underlying drivers of change within the insurance industry across the world and great moves by insurtechs have seen the rise of innovations towards customer experience (IIF, 2016). In recent times the insurance sector globally with the evolution of digital platforms, has focused quite heavily on technology solutions to enhance their services ranging from automated processes, use of telematics in motor insurance, building systems, and more recently, applying artificial intelligence and application programming interface in their activities. 
In an increasing competitive global market, organisations within this sector have come to understand innovation as an important component in the drive to meet up with the constantly changing demographic and technological competition. Empirical evidence suggests that innovation thrives in a setting where frontrunners are able to see possible connections, spot chances and take advantage of them. And that organisations who imbibe innovation along with the application of better productive process, tend to have a more positive customer perception (Gundaya, Ulousoy, Kilic \& Alpkan, 2011). Economists concur that innovation is responsible for a considerable proportion of progress in the profitability of organisations and that innovation thrives in a setting where frontrunners are able to see possible connections, spot chances and take advantage of them (Chatterji, Glaeser \& Kerr, 2013; Abongo, Mutinda \& Otieno, 2019). According to AIO (2018) the insurance industry across the globe has grown tremendously and in Africa, this growth is led by South Africa at an outstanding $14.2 \%$, Kenya at 3\% and Ghana at $1 \%$. While the sector is plagued with a few challenges as earlier highlighted, some repeatedly identified ones are low penetration, poor awareness, low trust level, and regulatory stiffness amongst others. To drive the continued growth of the sector, and help address the perennial problems, there is a need to embrace innovation.

According to Lambert and Davidson (2013), a business model is a value creation design by which an insurance company creates value to its clients and is embedded with delivery mechanism. Most companies use a model by which they are well identified and this signifies the type of offerings they provide to their clients The business models are often very rigid in nature, constraining and prolonged in terms of response times (McGrath, 2010). Traditional models of agency, brokerage and bancassurance in the distribution and marketing of their products and services have been the norm (Gera, Costonis, Sandquist, Bramblet \& Secchi, 2018) while the Nigerian model is commonly a revenue generation focused one where sale of policy is the major indicator (Mudaly, 2017). However, of recent, the enforcement of a customer-based approach has been included in the market conduct and business practice guidelines for insurance institutions issued by the National Insurance Commission (NAICOM).

Though these still constitute the major channels in most insurance markets, the recent entry of insurtechs start-ups providing insurance services are turning the tide of these old models (Kottmann \& Dordrechter, 2018). The market is a maze of forever changing scenarios across all fronts and this requires companies to implement very high-level expertise in its structure and service delivery (Ernst and Young, 2015). Though there have been some great signs of improvement within the Nigerian insurance sector, in comparison to other emerging markets, there is still room for more with a current penetration level of $0.3 \%$ in comparison to other countries both overseas and in Africa (AIO, 2018).

Insurance as a risk transfer mechanism is a socially germane to the economy, Innovation is an indispensable driver of change. The sector globally, is gradually embracing recent technological developments (Schanz, \& Sommerrock, 2016). The penetration rate and GDP contribution is quite discouraging and in need for a shift, with discussions around technology and innovation. The AIO (2018) noted that increasing levels of literacy and wealth have created a new middle class across the continent, thus increasing the pool of insurable assets and lives of an untapped potential market. They further noted that to increase penetration, strategies need to move from the previous inward looking to a more outer focused view through implementation of technology such as data analytics, internet of things and so on. Innovative technology will further aid ease of interaction and access to customers as well as client profiling, product design and quality service (Lehman, 2017). 


\subsection{Empirical Review}

Rajapathirana and Hui (2018) explored innovation capability and innovation type and their relationship to firm performance in Sri Lanka. The results observed that IC and innovation efforts had significant relationship with firm performance and concluded that effective innovation capability had the ability to assist insurance companies deliver more effective innovation outcomes. The study recommended that insurance companies apply this as it would help improve firm performance.

Czerniak and Klapkiv (2018) explored characterization of innovations of underwriting patents in the insurance market. The study results showed that there was no significant correlation between premium growth and the number of patents from the industry. The study concluded that innovation activity was a strong propellant for the insurance industry development. Hwang, Choi and Shin (2020) investigated the mediating role of IC in the relationship between individual level entrepreneurial competencies (EC) and firm level CA in Korean SMEs. Results showed that a stronger relationship between the indirect effects of EC through organisational innovation capabilities and CA than the direct effects. The study concluded that improving IC was beneficial and increased competitiveness. It recommended that firms should inculcate innovation capability to sustain their superior position. Abd Aziz and Samad (2016) investigated the moderating effect of firm age on the relationship between innovation and competitive advantage. Using SMEs in the food sector of Malaysia, the study employed structural equation modelling to test the hypotheses. The results revealed that innovation had a significant impact on competitive advantage and that firm age moderated the relationship. The study recommended that SMEs should invest in innovation to gain competitive advantage.

Waseem, Loo-See, Adeel and Riaz (2018) examined innovation capability and organisational performance. The study observed that intellectual capital dimensions portrayed substantial affirmative direct and indirect effects on organisational performance unlike structural capital which was found to be insignificant. Abongo et al., (2019) investigated the application of knowledge and skills in marketing of insurance in Kenya as an exchange driver and found that innovation capabilities were largely directed towards external rather than internal developments. The study also noted that these components had no impact on performance and that the companies had failed to sustain the innovative capabilities for the future. Anand and Monin (2013) reviewed innovation processes in emerging markets. The study identified seven processes and postulated that these processes responded to some basic issues in respect of values, affordability and accessibility. The study concluded that while these issues may also be existent in developed markets, they have higher prevalence in emerging markets and recommended that innovation processes within the service space aim to trigger evolution and development. Klapkiv and Klapkiv (2017) investigated technological innovations in the insurance industry. The study viewed the use of technologies such as analytics, algorithms and sensors within the industry and its effect on the value chain. Results showed that most of the processes within the value chain had been impacted by technology and concluded that whilst it had a positive impact, there might be increased dependence of the industry on other sectors.

Lerro, Linzalone and Schiuma (2014) who viewed described innovation capability from the perspectives of process, product, market and organisational innovation, investigated the role of innovation, intellectual capital, performance improvement and competitive advantage on an organisation's value creation. The study found certain assumptions and concluded that 
there was a need for organisations to have dynamic capabilities and also engage the passion and imagination of the public through innovation.

Hagen, Hales, Reifel, Pei and Miller (2009) examined technology as the pivot point in the insurance industry and noted five main trends currently and that technology could play a role in transforming the insurance industry. The findings of the study suggested that social networking, telematics and service-oriented architectures are essential to the growth of a competitive advantage. Chaudhry and Verma (2016) reviewed innovation capability evaluation factors and observed that innovation capability had a strong influence on an organization's competency and its capacity to sustain competitive advantage.

\section{METHODOLOGY OF RESEARCH}

The study employed a cross-sectional survey design. The study populace consisted of employees of 55 registered insurance companies in Nigeria across license types (composite business, general business and life business) (NAICOM, 2019). The target population consisted of employees of selected companies.

The sample size for this study was total enumeration of professional staff of the selected insurance companies. Stratified random sampling was used in the first stage to select thirty companies ranked into three groups comprising top ten from each license type (composite business, general business and life business). The justification for selection was based on organisations with operational location in Lagos State and shareholders' funds. These criteria are assumed to provide good liquidity base and act as a possible edge in terms of innovation. Six (6) companies were randomly selected in the second stage, with two companies from each of the group to ensure sufficient variance within the sample. Sample size of 150 was derived employing convenience sampling of 25 employees of each organisation. Data collection instrument was a questionnaire.

Measures for the study variables were adapted from extant literature. Measurement for innovation capability which was defined as the skill to continuously transform ideas and knowledge and convert the same to new products and systems beneficial to all stakeholders (Lerro et al., 2014), was done with ten items; competitive advantage defined as an organisation's advantage to outperform its competitors (Kay, 1994), was measured using nine items. The Cronbach Alpha for all scales were above the accepted range $(\alpha=0.70)$. Responses were elicited by means of a 5-point Likert scale of strongly agree at " 5 " to strongly disagree at "1". In line with the study of Wu \& Chen, (2011) the study included size of the company and age as control variables in order to account for the effects of extraneous variables. The organisation size was calculated using the employee size while the age was calculated using number of years of operation. The study employed regression analysis to test the relationship between the study variables.

\section{RESULTS}

Table 1 report the descriptive statistics, the mean and standard deviation of the study constructs.

Table 1 shows the result of the descriptive statistics of the study constructs. The results show that innovation capability items had a mean score range of between 3.50 and 4.17 with a reasonable distribution about this central tendency measure, while the standard 
deviation had a range between 0.722 and 1.007. The study results further show that competitive advantage measured with 9 items had a mean score range between 3.52 and 3.95 while the standard deviation had a range of between 0.754 and 0.954 .

Table 1 Descriptive Statistics

\begin{tabular}{|c|c|c|c|}
\hline \multicolumn{2}{|c|}{ Constructs Items Questionnaire description } & Mean & SD \\
\hline \multicolumn{4}{|c|}{ INNOVATION CAPABILITY } \\
\hline 1 & In my organisation, there is adequate funding for innovation & 4.01 & .995 \\
\hline 2 & There is a culture of risk taking in my organisation & 3.50 & 1.007 \\
\hline 3 & There is a process for innovation in my organisation & 3.75 & 1.018 \\
\hline 4 & In my organisation, there is recognition for innovation & 3.70 & .938 \\
\hline 5 & $\begin{array}{l}\text { There is development of new product, services and solutions in } \\
\text { my organization }\end{array}$ & 3.91 & 1.001 \\
\hline 6 & $\begin{array}{l}\text { My organisation, successfully introduced and implemented } \\
\text { innovative products/services }\end{array}$ & 3.72 & .933 \\
\hline 7 & $\begin{array}{l}\text { Our market ranking has increased due to innovation in my } \\
\text { organization }\end{array}$ & 4.17 & .760 \\
\hline 8 & There is a target for innovation in my organisation & 3.75 & 1.007 \\
\hline 9 & $\begin{array}{l}\text { We have savings due to our innovation strategy in my } \\
\text { organization }\end{array}$ & 3.59 & .912 \\
\hline 10 & $\begin{array}{l}\text { In my organisation, our research and innovation management is } \\
\text { excellent }\end{array}$ & 3.66 & .722 \\
\hline \multicolumn{4}{|c|}{ COMPETITIVE ADVANTAGE } \\
\hline 1 & The prices of our products are com & 3.59 & .954 \\
\hline 2 & $\begin{array}{l}\text { In my organisation, our products/services have unique benefits } \\
\text { than those of our competitors }\end{array}$ & 3.52 & .906 \\
\hline 3 & $\begin{array}{l}\text { Our products/services are of superior quality than those of our } \\
\text { competitors / We are able to compete based on quality }\end{array}$ & 3.57 & .800 \\
\hline 4 & $\begin{array}{l}\text { Our services are more advanced than those of competitors in the } \\
\text { same market in my organisation }\end{array}$ & 3.89 & .851 \\
\hline 5 & $\begin{array}{l}\text { In my organisation, our products/services are customized to } \\
\text { meet clients' need }\end{array}$ & 3.94 & .765 \\
\hline & $\begin{array}{l}\text { We respond to clients' request for new features in my } \\
\text { organization }\end{array}$ & 3.62 & .887 \\
\hline 7 & $\begin{array}{l}\text { In my organisation, our products/services are delivered on time } \\
\text { and to specification }\end{array}$ & 3.74 & .754 \\
\hline & $\begin{array}{l}\text { In my organisation, our products/services are the first to hit the } \\
\text { market }\end{array}$ & 3.53 & .861 \\
\hline 9 & Our product development is fast in my organisation & 3.95 & .809 \\
\hline
\end{tabular}

To effectively measure the relationship between the study variables in response to our hypothesis, the study employed regression analysis to test the relationship and the result is as shown in Table 2 and 3 below.

Table 2 shows the result of the study when the control variables of firm size and firm age are treated. The result indicates that firm size and firm age when controlled, have no significant relationship with competitive advantage $(\mathrm{F}=2.921 ; \mathrm{p}>.05)$. The results further show that $\left(\mathrm{R}^{2}=0.055\right)$, thus indicating that the control variables account for only $1 \%$ variation in competitive advantage. 
Table 2 Model Summary

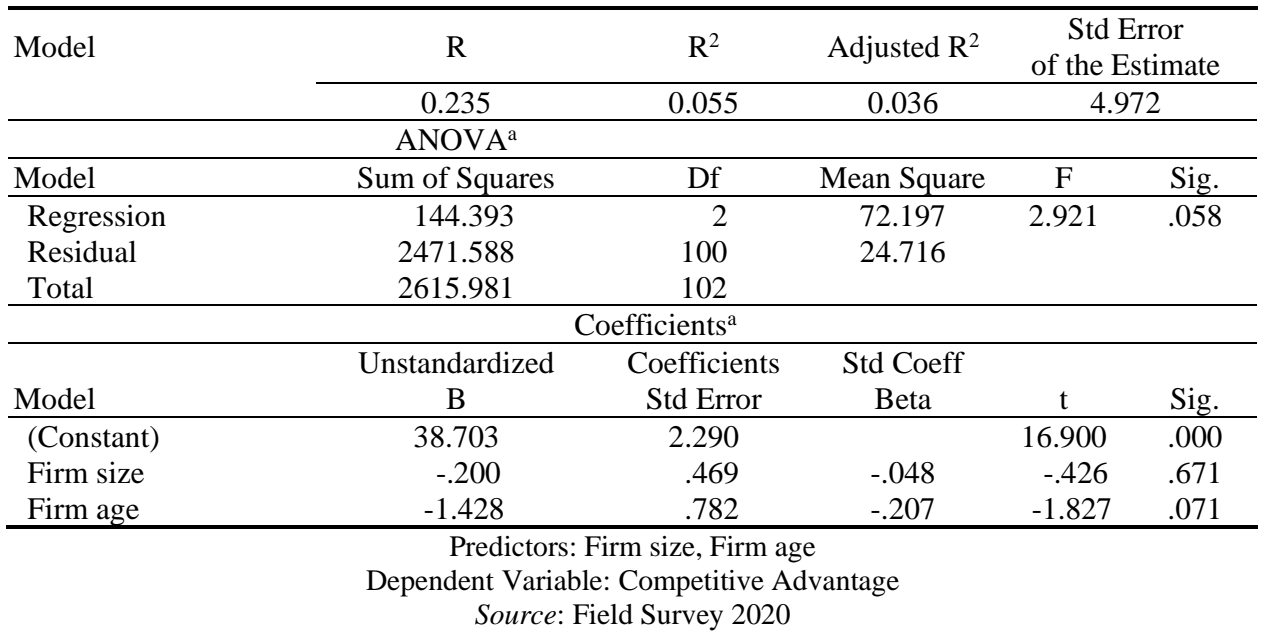

Table 3 shows the regression results when the study variables firm size, firm age and innovation capability are treated.

Table 3 Model Summary

\begin{tabular}{|c|c|c|c|c|c|}
\hline \multirow[t]{2}{*}{ Model } & $\mathrm{R}$ & $\mathrm{R}^{2}$ & Adjusted $\mathrm{R}^{2}$ & \multicolumn{2}{|c|}{$\begin{array}{c}\text { Std Error } \\
\text { of the Estimate }\end{array}$} \\
\hline & 0.628 & 0.395 & 0.377 & \multicolumn{2}{|c|}{3.998} \\
\hline \multicolumn{6}{|c|}{$\mathrm{ANOVA}^{\mathrm{a}}$} \\
\hline Model & Sum of Squares & df & Mean Square & $\mathrm{F}$ & Sig. \\
\hline Regression & 1033.272 & 3 & 344.424 & 21.544 & $.000^{\mathrm{b}}$ \\
\hline Residual & 1582.708 & 99 & 15.987 & & \\
\hline Total & 2615.981 & 102 & & & \\
\hline \multicolumn{6}{|c|}{ Coefficients $^{\mathrm{a}}$} \\
\hline & Unstandardized & Coefficients & Std Coeff & & \\
\hline Model & $\mathrm{B}$ & Std Error & Beta & $\mathrm{t}$ & Sig. \\
\hline Firm size & -.303 & .378 & -.073 & -.801 & .425 \\
\hline Firm age & -.742 & .635 & -.107 & -1.168 & .246 \\
\hline Innovation Capability & .515 & .069 & .590 & 7.457 & .000 \\
\hline
\end{tabular}

Dependent Variable: Competitive Advantage

Source: Field Survey 2020

The results in the model summary show correlation amongst the study variables with $\mathrm{R}=$ 0.628 . The result also shows that $R^{2}=0.395$, suggesting that $39.5 \%$ variation in competitive advantage is due to innovation capability, firm size and age with an unexplained $61.5 \%$ outside the scope of this study. The Anova results reflect a positive significant relationship between the study variables in the model $(\mathrm{F}=21.544 ; \mathrm{p}<.05)$. Furthermore, the results show that innovation capability makes a significant contribution to the overall model $(\beta=0.590 ; \mathrm{t}=$ $7.457, \mathrm{p}<0.05)$. Therefore, the null hypothesis cannot be accepted, meaning that innovation capability does have an influence on competitive advantage after controlling for firm size and firm age. 


\section{DISCUSSION AND CONCLUSION}

Using selected companies with emphasis on the underwriting process within the companies, this study examined the relationship between innovation capability and competitive advantage in Nigerian insurance companies. The study results showed that innovation capability had a significant relationship with competitive advantage. The results align with the study of Chaudhry and Verma (2016) who notes that innovative organisations tend to do better than organisations that are not very innovative. The study findings in relation to the contributions of innovation capability on competitive advantage corroborate existing studies (Hagen, Hales, Reifel, Pei \& Miller, 2009; Czerniak \& Klapkiv, 2018) who observe that technology played a pivotal role in the required transformation and development of the insurance industry market. The results also agree with the study of Klapkiv and Klapkiv (2017) that processes within the insurance value chain had been impacted by technology.

However, the result of this study extends the literature on innovation capability further, with emphasis on the underwriting process within the context of developing countries like Nigeria. A very critical component of the insurance contract is the underwriting process. And one of the important areas within this process is the risk assessment and premium rating. Having correct estimates from these two activities assists the organisation derive accurate results in terms of premiums charged, which translates to income which in turn aids financial stability. This study results in general highlight the importance of innovation capability and the need for the insurance industry in Nigeria to take cognizance of this capability and its potential to assist achieve competitive advantage. The study concludes that insurance companies maximizing this potential focus on improving and harnessing the same across all operational functions rather than engage in a rate cutting war.

The study results however, should be considered in light of some limitations which include the number of participants and the use of cross-sectional survey. Expansion in the participants and a longitudinal research is suggested for future studies. This study looked at underwriting process, deviating from the usual focus on product and customer. Future studies should look at other units within the organisation. The population of the study was limited. It is thus suggested that the population be expanded for future research.

The study contributes to existing literature on innovation capability and competitive advantage by considering the impact on underwriting process within the insurance market in Nigeria. The policy implication is that global market and customers are aligning more with industry players who have the capability to meet the requirements, immediate interactions and play internationally, which are only enabled through innovative techniques. Thus, insurance firms should harness available growth in the technology space as this is a key factor to their ability to sustain competitive advantage. The study further recommended that insurance companies in Nigeria understand and exploit intangibles as valuables, especially in terms of innovation capability, identify and harness innovation capability through adequate investments and align with market shifts to help improve competitive advantage.

\section{REFERENCES}

Aas, T. H., \& Breunig, K. J. (Eds.). (2017). Innovation Capabilities: Affirming an Oxymoron?. Fundation for the Dissemination of Knowledge and Science" Cognitione".

Abongo, B., Mutinda, R., \& Otieno, G. (2019). Innovation capabilities and process design for business model transformation in Kenyan insurance companies: A service dominant logic paradigm. Journal of Information 
and Technology, 3(1), 15-45. Retrieved from http://stratfordjournals.org/journals/index.php/Journal-ofInformation-and-Techn/article/view/297

AIO. (2018). Africa insurance barometer: Market survey. African Insurance Organisation, 1-49. Retrieved from: http://turnkeyafrica.com/africa-insurance-barometer-2018/

Alsamydai, M. J., Alnawas, I. A. M., \& Yousif, R. A. (2010). The impact of marketing innovation on creating sustainable competitive advantage: The case of private commercial banks in Jordan. Asian Journal of Marketing, 4, 113-130.

Anand, M., \& Monin, P. (2013). Innovation processes in emerging markets: Empirical evidence from the Indian insurance industry. Management International, 18(1), 40-57.

Barney, J. (1991). Firm resources and sustained competitive advantage. Journal of management, 17(1), 99-120.

Barney, J. B., \& Clark, D. N. (2007). Resource-based theory: Creating and sustaining competitive advantage ( $1^{\text {st }}$ ed.) Oxford University Press on Demand

Barney, J. B., \& Hesterly, W. S. (2009). Strategic management and competitive advantage. Upper Saddle River, $\mathrm{NJ}$ : Pearson Education.

Bell, M., \& Figueiredo, P. N. (2012). Innovation capability building and learning mechanisms in latecomer firms: Recent empirical contributions and implications for research. Canadian Journal of Development Studies/Revue canadienne d'études du développement, 33(1), 14-40.

Calantone, R. J., Cavusgil, S. T., \& Zhao, Y. (2002). Learning orientation, firm innovation capability, and firm performance. Industrial marketing management, 31(6), 515-524.

Cassiman, B., \& Golovko, E. (2011). Innovation and internalization through exports. Journal of International Business Studies, 42(1), 56-75.

Cavusgil, S. T., Calantone, R. J., \& Zhao, Y. (2003). Tacit knowledge transfer and firm innovation capability. Journal of Business \& Industrial Marketing, 18(1), 6-21.

Chadha, A. (2009). Product cycles, innovation and exports: A study of Indian pharmaceuticals. World Development, 37(9), 1478-1483.

Chatterji, A., Glaeser, E., \& Kerr, W. (2014). Clusters of entrepreneurship and innovation. Innovation policy and the economy, 14(1), 129-166.

Chaudhry, B., \& Verma, P. K. (2016). Technological innovation capabilities: a critical review. International Journal of Latest Technology in Engineering, Management \& Applied Science, 5(4), 95-101.

Chen, L., Zhou, Y., Zhou, D., \& Xue, L. (2017). Clustering enterprises into eco-industrial parks: Can interfirm alliances help small and medium-sized enterprises?. Journal of Cleaner Production, 168, 1070-1079.

Christensen, K. \& Fahey, L. (1984). Building distinctive competencies into competitive advantage. Strategic Planning Management, 2(1), 113-123.

Czerniak, J., \& Klapkiv, L. (2018). Innovations on the insurance market: Patents in underwriting. Handel Wewnetrzny, 6, 151-163.

Desai, A. V. (1984). India's technological capability: An analysis of its achievements and limits. Research Policy, 13(5), 303-310. Retrieved from: https://ideas.repec.org/a/eee/respol/v13y1984i5p303-310.html

Eisenhardt, K. M., \& Martin, J. A. (2000). Dynamic capabilities: what are they?. Strategic Management Journal, 21(10-11), 1105-1121.

Ernst \& Young (2015). Sustaining growth and innovation in the insurance sector. Insurance Governance Leadership Network Summit, November 2015. Retrieved from https://www.ey.com/Publication/vwLUAssets/EY-iglnsummit-sustaining-growth-and-innovation/\$FILE/EY-IGLN-Summit-Sustaining-growth-and-innovation.pdf

Gera, P., Costonis, M., Sandquist, E., Bramblet, J., \& Secchi, A. (2018). Insurance as a living business: Explosive growth. Accenture. Retrieved from https://www.accenture.com/t00010101T000000Z_w_/ares/_acnmedia/PDF-72/Accenture-Insurance-Living-Business-POV.pdf

Gloet, M., \& Samson, D. (2016). Knowledge management and systematic innovation capability. International Journal of Knowledge Management, 12(2), 54-72.

Gnatzy, T., \& Moser, R. (2012). Scenario development for an evolving health insurance industry in rural India: INPUT for business model innovation. Technological Forecasting and Social Change, 79(4), 688-699.

Gunday, G., Ulusoy, G., Kilic, K., \& Alpkan, L. (2011). Effects of innovation types on firm performance. International Journal of production economics, 133(2), 662-676.

Hagen, C., Hales, M., Reifel, J., Pei, A., \& Miller, J. (2009). Technology: the insurance industry's pivot point. A.T. KEARNEY, 1-7.

Hill, L. A., Brandeau, G., Truelove, E., \& Lineback, K. (2015). The capabilities your organization needs to sustain innovation. Harvard Business Review, 1-9.

Hwang, W., Choi, H., \& Shin, J. (2020). A mediating role of innovation capability between entrepreneurial competencies and competitive advantage. Technology Analysis \& Strategic Management, 32(1), 1-14.

Iddris, F. (2016). Innovation capability: A systematic review and research agenda. Interdisciplinary Journal of Information, Knowledge, and Management, 11, 235-260. 
IIF. (2016). Innovation in insurance: How technology is changing the industry. Institute of International Finance, pp. 1-12. Retrieved from https://www.iif.com/Publications/ID/1246/Innovation-in-Insurance-How-Technology-isChanging-the-Industry

Katz, J. (1984). Domestic technological innovations and dynamic comparative advantage. Journal of Development Economics, 16(1/2), 13-37.

Kimani, M., \& Juma, W. (2015). Assessment of strategies for gaining competitive advantage in insurance firms in Thika Town, Kenya. International Journal of Economics, Commerce and Management, 3(2), 1305-1316.

Klapkiv, L., \& Klapkiv, J. (2017). Technological innovations in the insurance industry. Journal of Insurance, Financial Markets and Consumer Protection, 26(4/2017), 67-78.

Kottmann, D., \& Dordrechter, N. (2018). Insurtech caught on the radar hype or the next frontier? Oliver Wyman/Policendirekt, Global Insurtech Report, 1-52. Retrieved from https://www.oliverwyman.com/ourexpertise/insights/2017/may/InsurTech-caught-on-the-radar.html

Lall, S. (1992). Technological capabilities and industrialization. World development, 20(2), 165-186.

Lambert, S. C., \& Davidson, R. A. (2013). Applications of the business model in studies of enterprise success, innovation and classification: An analysis of empirical research from 1996 to 2010. European management journal, 31(6), 668-681.

Lehman, M. (2017). How will insurtech influence claims?. Accenture Insurance Blog, 1-4. Retrieved from insuranceblog.accenture.com

Lerro, A., Linzalone, R., \& Schiuma, G. (2014). Managing intellectual capital dimensions for organizational value creation. Journal of Intellectual Capital, 15(3), 350-361.

Li, S., Ragu-Nathan, B., Ragu-Nathan, T. S., \& Rao, S. S. (2006). The impact of supply chain management practices on competitive advantage and organizational performance, Omega, 34(2), 107-124.

Mahdi, O. R., Nassar, I. A., \& Almsafir, M. K. (2019). Knowledge management processes and sustainable competitive advantage: An empirical examination in private universities. Journal of Business Research, 94, 320-334

Maina, M. N. (2016). Effect of innovation strategies on the performance of insurance firms in Kenya. Unpublished Master of Science in Entrepreneurship and Innovations Management thesis, University of Nairobi. UON Repository.

Massey, B. L. (2016). Resource-based analysis of the survival of independent web-native news ventures. Journalism \& Mass Communication Quarterly, 93(4), 770-788.

Mathur, D., \& Tripathi, A. S. H. I. S. H. (2014). Factors influencing customer's choice for insurance companies: A study of Ajmer City. IOSR Journal of Business Management, 16(2), 35-43.

McGrath, R. G. (2010). Business models: A discovery driven approach. Long range planning, 43(2-3), $247-261$.

Mudaly, N. A. (2017). Business model innovation: the drivers, enablers and inhibitors of firms facing disruptive change (Doctoral dissertation, University of Pretoria). Retrieved from: URI: http://hdl.handle.net/2263/59891

National Insurance Commission (NAICOM) 2019. Retrieved from https://www.naicom.gov.ng

NIA (2019). 2018 Nigeria Insurers Digest

OECD. (2005). OECD science, technology and industry scoreboard, OECD, Paris. Retrieved from https://www.oecd. org/sti/scoreboard.htm

Peteraf, M. A. (1993). The cornerstones of competitive advantage: A resource-based view. Strategic Management Journal, 14(3), 179-191.

Peteraf, M. A., \& Barney, J. B. (2003). Unravelling the resource-based tangle. Managerial and Decisions Economics, 24(4), 309-323.

Porter, M. E. (1985). Technology and competitive advantage. Journal of Business Strategy, 5(3), 60-78.

Porter, M. (1996). What is strategy? Harvard Business Review, 74(6), 61-78.

PwC (2015). Africa insurance trends. Retrieved from https://www.pwc.com/ng/en/assets/pdf/nigeria-insurancesurvey.pdf

Rajapathirana, R. J., \& Hui, Y. (2018). Relationship between innovation capability, innovation type, and firm performance. Journal of Innovation \& Knowledge, 3(1), 44-55.

Rua, O., França, A., \& Ortiz, R. F. (2018). Key drivers of SMEs export performance: the mediating effect of competitive advantage. Journal of Knowledge Management

Schanz, K. U., \& Sommerrock, F. (2016). Harnessing technology to narrow the insurance protection gap. Report/The Geneva Association: Zurich. Retrieved from https://www.genevaassociation.org/sites/default/files/research-topicsdocument-type/pdf_public/harnessing-technology-to-narrow-the-insurance-protection-gap.pdf

Shan, S., Luo, Y., Zhou, Y., \& Wei, Y. (2019). Big data analysis adaptation and enterprises' competitive advantages: the perspective of dynamic capability and resource-based theories. Technology Analysis \& Strategic Management, 31(4), 406-420.

Slater, S. F., Mohr, J. J., \& Sengupta, S. (2014). Radical product innovation capability: Literature review, synthesis, and illustrative research propositions. Journal of Product Innovation Management, 31(3), 552-566.

Stevenson, W. J. (2009). Operations management $\left(10^{\text {th }}\right.$ ed,). McGraw-Hill Irwin Higher Education. 
Vicente, M., Abrantes, J. L., \& Teixeira, M. S. (2015). Measuring innovation capability in exporting firms: The INNOVSCALE. International Marketing Review, 32, 29-51.

Waseem, B., Loo-See, B., Adeel, A., \& Riaz, A. (2018). Impact of intellectual capital on innovation capability and organizational performance: An empirical investigation. Serbian Journal of Management, 13(2), 365-379.

Wernerfelt, B. (1984). A resource-based view of the firm. Strategic management journal, 5(2), 171-180.

Wu, X., Gu, Z., \& Zhang, W. (2008). The construction of innovation networks and the development of technological capabilities of industrial clusters in China. International Journal of Innovation and Technology Management, 5(02), 179-199.

Wu, J., \& Chen, X. (2011). Leaders social ties, knowledge acquisition capability and firm competitive advantage. Asia Pacific Journal of Management, 29(2), 331-350.

Zawislak, P. A., Fracasso, E. M., \& Tello-Gamarra, J. (2018). Technological intensity and innovation capability in industrial firms. Innovation \& Management Review, 15(2), 189-208.

Zhou, Y., Pan, M., \& Urban, F. (2018). Comparing the international knowledge flow of China's wind and solar photovoltaic (PV) industries: Patent analysis and implications for sustainable development. Sustainability, 10(6), 1883.

\section{KONKURENTNA PREDNOST NIGERIJSKE INDUSTRIJE OSIGURANJA: ULOGA INOVACIONE SPOSOBNOSTI}

Nove tehnologije su omogućile veće mogućnosti u okviru sektora osiguranja, gde su inovacije preokrenule tradicionalni biznis model. Ovaj rad proučava konkurentnu prednost i njen odnos sa sposobnošću za inovacije nigerijskog sektora osiguranja. Uz pomoć međusektorskog dizajna istraživanja, studija koristi primarne podatke dobijene od odabranih osiguravajućih kompanija uz pomoć strukturisanog upitnika. Korišćena je tehnika višefaznog uzrokovanja, a dobijeni podaci su analizirani uz pomoć regresivne analize. Rezultati su pokazali da je sposobnost za inovacije imala značajnog uticaja na komparativnu prednost. Studija zaključuje da postoji potreba da se obrati pažnja na ovu sposobnost sa mogućnošću da se pojačaju aktivnosti industriuje i date su preporuke.

Ključne reči: konkurentna prednost, osiguranje, inovaciona sposobnost 